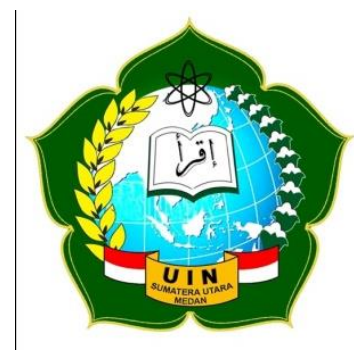

VISION JOURNAL

http://jurnaltarbiyah.uinsu.ac.id/vision

E-ISSN 2745-7982

\title{
A WRITING SKILL ASSESSMENT OF THE FIRST SEMESTER ENGLISH DEPARTMENT STUDENTS OF THE UNIVERSITAS SUMATERA UTARA Tania Tita Shanorra ${ }^{1}$, Rudy Sofyan ${ }^{2}$, Desri Maria Sumbayak ${ }^{3}$
}

Email: taniatitashanorra@ students.usu.ac.id, rudy sofyan@yahoo.com, desrisumbayak@gmail.com

${ }^{1,2}$ Department of English Literature, University of Sumatera Utara

\begin{tabular}{|l|l|}
\hline Keywords & Abstract \\
\hline $\begin{array}{l}\text { Keywords: English, writing, } \\
\text { ability, language, assessment }\end{array}$ & $\begin{array}{l}\text { This study attempts to measure the students' abilities in writing } \\
\text { through online language learning platform using library } \\
\text { research. The subject of the research was TOEFL top score in } \\
\text { English Department USU consisting of 19 students. The } \\
\text { instruments of collecting data were the students writing e- } \\
\text { portfolio as the quantitative and qualitative data. Based on the } \\
\text { assessment process, the used of online learning platform was } \\
\text { very helpful, effective, and efficient both for the teachers and } \\
\text { the students. The findings of the research: (1) Content aspect } \\
\text { score was 25.7; (2) Organization aspect score was 18.1; (3) } \\
\text { Vocabulary aspect score was 18.3; (4) Language use aspect } \\
\text { score was 19.7; (5) Mechanics aspect score was 4.3. The result } \\
\text { of the research showed that the students experienced mostly in } \\
\text { excellent to very good level. }\end{array}$ \\
\hline
\end{tabular}

Faculty of Cultural Sciences

Jalan Universitas No. 19, Padang Bulan, Kec. Medan Baru, Kota Medan, 20155

Telp. 061- 8223530

\section{INTRODUCTION}

English as a foreign language (EFL) mostly studied in worldwide, included in Indonesia. It can be studied by these four component skills: listening, speaking, reading, and 
writing. Writing is one of the four basic skills. White (1986:10) defines that writing is the process of expressing the ideas, information, knowledge, or experience and understand the writing to acquire the knowledge or some information to share and learn. According to Bram (1995: 3), he states that "writing is producing or reproducing written message." It is a functioning cycle to compose and plan the thoughts on the paper. In this manner, before started to compose the paper it has to figure out what the author shall have something meaningful to convey. The term of ability is defined as skill or power. Concisely, writing ability is the skill to express ideas, thoughts, and feelings to other people in written symbols to make other people or readers understand the ideas conveyed (Morris, 1999: 22).

There are some reasons why language learners should master how to write paragraph in a good form. A person needs a mastery of various elements to use the language to convey thoughts, wishes, intentions, feeling and information in a written form (Pamela, 1991). First, writing is a part of a communication through written text that is beneficial for students. Second, English writing is a part of human activities nowadays. Globalization era makes all compete fiercely in the fields of business and education. Then, by mastering writing, someone could express their feelings more comfortable rather than express it verbally. One of the difficulties in the language learning process can be through writing since there are many aspects in writing such as: content, organization, vocabulary, language use, and mechanics. In what Oxford University Press ELT blog (2015) has assumed writing is hard by explaining the reasons why writing is difficult can be caused by: (1) They are on their own; (2) Topics can be uninspiring; (3) Too much feedback is counter-productive. Indeed, even sometimes the English native speaker face inconvenience in a difficult situation. In writing, Jacobs et al (1981:31) listed out five critical components. These are content, organization, vocabulary, language use and mechanics. Content is a planning, writing, and editing process to make the text is clear and can be understood. Organization is how the writer arrange and organize and the idea chronologically. Vocabulary is the language aspects of word choice. Language use is a correct usage of the rules of language or grammar that focuses on verbs, nouns, and agreements. Mechanics is dealing with capitalization, punctuation and spelling appropriately.

The student's high or low writing skill often be found by many factors. It can be caused by the teacher, students, environment, writing assessment, and the other aspects. For a teacher, giving an assessment of a student's writing work is a common way to find out which deficiencies have to be fixed by students. This can make students' writing skills improve from some of the mistakes they made previously. According to Brown (2004), he stated that 
assessment is an ongoing process which is a part of the teaching and learning process. Assessment is an important tool to review student's achievement that can be useful for an information to students and teachers in language learning. Students are able to improve their skills in writing by evaluating and controlling their own learning process and teacher also can be used the assessment as a material for teaching developments. The difficulty in assessing student assignments is often encountered, especially with the provision of adequate tools and facilities. Like what Redecker (2013) said "the main challenge to the use of ICT for the assessment of Key Competences is the lack of software solutions - electronic tools, programs or environments - that are comprehensive and versatile enough to support curricular based classroom teaching and learning". Some software in the application of the assessment process does not provide accurate and complete results. In addition, the situation in the institution probably does not introduce the advantages and effectiveness of teaching and learning process using technology. However, using software to aid in more tedious analyzes has many potential benefits. According to Ripley (2009), he stated "assessing test using computer also have a positive effect on students' motivation, concentration and performance; provide teachers with access to high quality materials; thanks to automatic scoring teachers can focus on analysis and interpretation of assessment results; and, more recently, e-assessment applications are being developed which provide learners and teachers with detailed reports that describe strengths and weaknesses, thus supporting formative assessment." It is very profitable to do paperless language learning which is more modern and sophisticated. Also, this is an advancement in knowledge and a future trend that promises variations such as from increasing digital technology-based easily way in teaching and learning to the emergence of virtual conveniences that ensure adaptable learning situations.

By considering the importance of writing skill especially for students, the objectives in conducting this research tries to explain the assessment of students' writing skills works and to find out the student's competency in writing.

\section{LITERATURE REVIEW}

\section{Theoritical Framework}

The four basic language skills are Listening, Speaking, Reading, and Writing. These four capabilities allow individuals to understand, produce, and use the language in interpersonal communication effectively. Listening and reading are included as receptive skills that means the learner does not need to produce language to do it. Meanwhile, speaking and writing are 
productive skill because the learner needs to do it to produce language. A person needs a mastery of various elements to use the language to convey thoughts, wishes, intentions, feeling and information in a written form (Pamela, 1991). By mastering a good level of English, students are able to understand and produce language well.

\section{The Nature of Writing}

The definition of writing itself can be stated by some experts. White (1986:10) defines "writing is the process of expressing the ideas, information, knowledge, or experience and understand the writing to acquire the knowledge or some information to share and learn." Besides that, Bram (1995: 3) states that "writing is producing or reproducing written message. It is a functioning cycle to compose and plan the thoughts on the paper." In this manner, before started to compose the paper it have to figure out what the author shall have something meaningful to convey. The term of ability is defined as skill or power. Concisely, Morris (199:22) explained "writing ability is the skill to express ideas, thoughts, and feelings to other people in written symbols to make other people or readers understand the ideas conveyed."

\section{Components in Writing}

In writing, Jacobs et al (1981: 31) listed out five critical components. These are content, organization, vocabulary, language use and mechanics.

\section{Content}

Content is a planning, writing, and editing process to make the text is clear and can be understood. In order for the reader to understand what message is conveyed by the author, the substance of the writing needs to be clear. Also, in content should be well unified and completed in order to provide a good text in writing. This is usually called unity and completeness, which is the product of good writing.

A good paragraph needs to have unity, where only one main idea is addressed in each paragraph. If the author is going to bring forward a new idea, then begin with a new paragraph. The supporting sentence in the sentence, then, should directly relate to the main idea. Using content that does not really clearly support the subject sentence is incorrect.

In the key definition, completeness has a concept that must be completely described and developed as a commentary on the controlling idea that is extensively developed by 
certain information in the text. It is required that the complete material of the writing is clear and easily understood to readers.

\section{Organization}

The writer reflects on how he chronologically arranges and organizes ideas when compiling the text. From the beginning to the end of the idea, presenting the idea in a chronological order is a must. There are several forms for writing to be structured and coordinated. This organization is also primarily recognized as an order.

There is a definition to coherence which sticks together. All ideas are connected to one another in a coherent text. A coherent paragraph is one in which all the thoughts are correctly ordered and the reader is never confused. In the following sentences and paragraphs in an article, writers are required to make efforts.

3. Vocabulary

One aspect of language related to the learning process in writing is vocabulary. In a process of writing text, the writer always thinks of the right way to put the words into sentences creatively and appropriately which then puts the sentences into paragraphs. Subsequently, with this the text can produce understandable writing. So, with the ability to master various word choices, this can help develop a more varied writing with a writing style that is not monotonous.

\section{Language use}

Language use in writing implicates correct form of the decrees of language or grammar. It focuses on verbs, nouns, and agreements. More specialized nouns and stronger verbs provide the reader with a mental picture of the description more vividly. This specific noun can be characterized by using modifier of adjective, adverbs, and participle forms. There are lots of opportunities for errors in the use of verbs and for very common misconceptions. Having the opportunity to reread and review what the author has written can reduce errors.

\section{Mechanics}

Mechanics in writing deal with capitalization, punctuation and spelling appropriately. This aspect is very important in terms of directing the reader to understand or recognize what the writer means with certainty. The use of good mechanisms in writing will make it easier for readers to understand the ideas of conveying messages or information that are stated in the writing. 


\section{a. Capitalization}

In writing, the use of capitalization will clarify the ideas. In addition, the proper use of capital letters enables the reader to separate one sentence from another. b. Punctuation

It can be used as a unit of meaning and suggestion and how its relation units are connected to each other.

c. Spelling

In using correct spelling, there are three significant rules to be followed. They are suffix addition, plural formation and error of handling within the words.

Bram (1995: 13) says that "a paragraph is a group of sentences which contain relevant information about one main or central ideas.” A good paragraph has topic sentences, preferably placed at beginning a number of supporting sentences, and a concluding sentence. Each type of sentences plays an important different role (Bram, 1995: 13). According to Hornby (1963), he defines "a paragraph is a group of several sentences dealing with main idea of a piece of writing, starting on a new line."

\section{Assessment in Writing}

According to the Centre for Advancement of Learning and Teaching of University of Tasmania (2011), it is said "assessment is an essential part of language teaching and learning. It can be said that it is a process of making judgment related to the students' achievements in their learning in a particular period." It is included as evaluation activities, writing the rubric, assessing the achievement of the students based on those tasks, providing students with feedback, and specifying grades. Brown (2004) stated that "assessment is an ongoing process that includes various aspects within." He mentions that there are two types of assessments: formal and informal assessment. Formal assessment is a planned and designed process that is used to see the success of students in their learning. Informal assessment, on the other hand, is a spontaneous response to the students, such as unplanned feedback and suggestions. According to Siozos et al (2009), he said "there are two main types of assessment systems: Paper Based System (PBS) and Computer Based System (CBS)." PBS is gradually being separated from learning practices as the spread of Information and Communication Technology (ICT) continues. At the same time, due to the success of ICT, CBS is replacing PBS. 
Journal VISION, Vol. XVII. No.2 (July-Desember 2021). Page 1-19

Table I. of Scoring Rubric for Writing Skills by Jacobs et al

\begin{tabular}{|c|c|c|}
\hline Aspect of Writing & Score & Category \\
\hline Content & $\begin{array}{l}30-27 \\
26-22 \\
21-17 \\
16-13\end{array}$ & $\begin{array}{l}\text { Excellent to very good } \\
\text { Good to average } \\
\text { Fair to poor } \\
\text { Very poor }\end{array}$ \\
\hline Organization & $\begin{array}{c}20-18 \\
17-14 \\
13-10 \\
9-7\end{array}$ & $\begin{array}{l}\text { Excellent to very good } \\
\text { Good to average } \\
\text { Fair to poor } \\
\text { Very poor }\end{array}$ \\
\hline Vocabulary & $\begin{array}{c}20-18 \\
17-14 \\
13-10 \\
9-7\end{array}$ & $\begin{array}{l}\text { Excellent to very good } \\
\text { Good to average } \\
\text { Fair to poor } \\
\text { Very poor }\end{array}$ \\
\hline Language Use & $\begin{array}{c}25-22 \\
21-18 \\
17-11 \\
10-5\end{array}$ & $\begin{array}{l}\text { Excellent to very good } \\
\text { Good to average } \\
\text { Fair to poor } \\
\text { Very poor }\end{array}$ \\
\hline Mechanics & $\begin{array}{l}5 \\
4 \\
3 \\
2\end{array}$ & $\begin{array}{l}\text { Excellent to very good } \\
\text { Good to average } \\
\text { Fair to poor } \\
\text { Very poor }\end{array}$ \\
\hline
\end{tabular}

There are three types of scoring method for responsive writing. They are holistic, primary trait, and analytical scoring (Brown, 2004). According to Weigle (2002), it is said "holistic scoring is used to judge the students' writing by assigning a single score after reading the 
overall text." Weigle (2002) says that "analytical scoring is used to assess the students' writing based on the aspects of writing such as content, organization, vocabulary, language use, and mechanics." Primary trait scoring can be used to know "how well students can write within a narrowly define range of discourse" (Weigle, 2002:110). It means that this scoring assesses writing based on its function (Brown, 2004).

\section{METHOD}

The research used library research as the data collection method. Technique of data collection is from Miles and Huberman (1994) which is included data reduction, data display, conclusion drawing/verification and quantitative used to find out the class mean score in general. This research used the target population and the technique of sampling used quota sample included 19 students who have 500+ score result in TOEL test. The primary data sources taken from the student's writing exercise on platform. It obtains from all words, phrases and sentences in the text. The secondary data are the supporting data taken from any information of assessment such as related articles and journals in reference of further guidance.

\section{FINDING AND DISCUSSION}

\section{Finding}

The performance of different variables in students' writing competency namely content, organization, vocabulary, language use, and mechanics was analyzed separately. The competency in writing sub-skill was evaluated on the basis of scoring rubric by Jacobs et al (1981) five components. It is included: (1) Content, e.g. (i) Excellent to very good $=30-27$, (ii) Good to average $=22-26$, (iii) Fair to poor $=21-17$, (iv) Very poor $=13-16$; (2) Organization, e.g. (i) Excellent to very good $=20-18$ (ii) Good to average $=17-14$, (iii) Fair to poor $=13-10$, (iv) Very poor $=9-7$; (3) Vocabulary e.g. (i) Excellent to very good $=20-18$, (ii) Good to average $=17-14$, (iii) Fair to poor $=13-10$, (iv) Very poor $=9-7$; (4) Language use, e.g. (i) Excellent to very good $=25-22$, (ii) Good to average $=21-18$, (iii) Fair to poor $=17-11$, (iv) Very poor $=10-5$; (5) Mechanics, e.g. (i) Excellent to very good = 5, (ii) Good to average $=4$, (iii) Fair to poor $=3$, (iv) Very poor $=2$. 
Journal VISION, Vol. XVII. No.2 (July-Desember 2021). Page 1-19

Table II. Descriptive Score in Writing Source

\begin{tabular}{|c|c|c|c|c|c|}
\hline \multirow{2}{*}{$\begin{array}{l}\text { Student's } \\
\text { Initial }\end{array}$} & \multicolumn{5}{|c|}{ Score } \\
\hline & Content & Organization & Vocabulary & $\begin{array}{c}\text { Language } \\
\text { Use }\end{array}$ & Mechanics \\
\hline $\mathrm{AH}$ & 25 & 16 & 18 & 18 & 4 \\
\hline DAFM & 29 & 17 & 19 & 21 & 5 \\
\hline SK & 29 & 20 & 19 & 21 & 4 \\
\hline MA & 25 & 17 & 17 & 19 & 4 \\
\hline SA & 20 & 15 & 17 & 18 & 5 \\
\hline $\mathrm{FS}$ & 29 & 20 & 18 & 25 & 5 \\
\hline JPB & 21 & 17 & 18 & 16 & 4 \\
\hline KA & 25 & 17 & 18 & 20 & 4 \\
\hline $\mathrm{ADP}$ & 28 & 18 & 18 & 22 & 4 \\
\hline FA & 25 & 19 & 17 & 19 & 3 \\
\hline KAK & 18 & 15 & 17 & 20 & 4 \\
\hline JCJR & 27 & 19 & 17 & 20 & 4 \\
\hline FGP & 28 & 19 & 20 & 21 & 4 \\
\hline RTP & 29 & 19 & 18 & 21 & 5 \\
\hline SRNJ & 18 & 18 & 19 & 20 & 5 \\
\hline $\mathrm{EE}$ & 28 & 20 & 19 & 22 & 4 \\
\hline ANS & 30 & 20 & 20 & 23 & 4 \\
\hline GS & 29 & 19 & 20 & 22 & 5 \\
\hline AKY & 27 & 19 & 20 & 22 & 5 \\
\hline TOTAL & 490 & 344 & 349 & 375 & 82 \\
\hline AVERAGE & 25.7 & 18.1 & 18.3 & 19.7 & 4.3 \\
\hline
\end{tabular}


The results of student's writing skill through the application of Computer Based Assessment (CBS) strategy could also be seen from the mean of the student's score in content, organization, vocabulary, language use, and mechanics aspects. The student's competency in content got average score 25.7 with the highest score was 30 and the lowest was 16 . The organization part based on the table above showed average 29.8 with the highest score was 20 and the lowest one was 13 . The average number of vocabulary was 18.3 with the highest score was 20 and the lowest one was 16. In language use aspect, it shows the total average 19.7 with the highest score was 21 and the lowest was 16. Mechanics aspect average score was 4.3 with the highest score was 5 and the lowest was 2.

It indicates that the students' scores in the part of content mostly found in 'excellent to very good' level, which contained 11 students. The next most positions were on the level of 'good to average' with the total number of participants was 4 and also 4 students experienced the level of 'fair to poor'. The next research finding is clearly shown that most students experienced 'excellent to very good' when they write in organization sub-skill included 12 participants, 7 participants had 'good to average', and no one students experienced 'fair to poor' and 'very poor' level. In the vocabulary type of sub-skills, it is found none of them had low scores, being almost entirely at the level of 'excellent to very good' with 14 participants and 5 participants was in 'very good to average' level. According to the table above, the student's performance in language use mostly found on 'good to average' position with the total number of participants were 12. There were 6 participants experienced the 'excellent to average' level and 1 participant experienced 'fair to poor' level in language use aspect. In the sub-skills of mechanics, the table shows the students' performance mostly remained 'good to average' in total of 11 participants, whereas 7 participants experienced 'excellent to very good'. There was a single participant experienced 'fair to poor', and no one experienced 'very poor' in writing by following the correct mechanics system. 
Table III. Descriptive Score Percentage

\begin{tabular}{|c|c|c|c|c|c|}
\hline & Content & $\begin{array}{c}\text { Organizatio } \\
\mathbf{n}\end{array}$ & Vocabulary & $\begin{array}{c}\text { Language } \\
\text { Use }\end{array}$ & Mechanics \\
\hline $\begin{array}{c}\text { Excellent to } \\
\text { very good }\end{array}$ & $57,8 \%$ & $63,2 \%$ & $73,7 \%$ & $31,5 \%$ & $36,8 \%$ \\
\hline $\begin{array}{c}\text { Good to } \\
\text { average }\end{array}$ & $21,1 \%$ & $32,8 \%$ & $26,3 \%$ & $63,2 \%$ & $57,9 \%$ \\
\hline Fair to poor & $21,1 \%$ & $0 \%$ & $0 \%$ & $5,3 \%$ & $5,3 \%$ \\
\hline Very poor & $0 \%$ & $0 \%$ & $0 \%$ & $0 \%$ & $0 \%$ \\
\hline
\end{tabular}

Table above presents the finding from research analysis in students' writing competency based on Jacob et al (1981) theory. 11 students $(57,8 \%)$ experienced excellent to very good in content where they could understand what they wrote on their assignment, 4 students $(21.1 \%)$ experienced in the level of 'good to average' and 4 students $(21.1 \%)$ faced difficulty in developing their ideas through the topic more explainable. 12 students $(63,2 \%)$ reported adept at composing sentences from the beginning of paragraph until the last part and 7 students $(36,8 \%)$ almost faced difficulty in organizing a well sequence of the text. 14 students $(73,7 \%)$ and 5 students $(26,3 \%)$ had writing skills in the aspect of good vocabulary so as to reach the levels of 'excellent to very good' and 'good to average'. There were 6 students $(31,5 \%)$ reported to have the ability to write in terms of perfect language use without errors, where 12 students $(63,2 \%)$ and 1 student $(5,3 \%)$ faced difficulty mostly in articles, agreements, tense, and constructions. 11 students (57,9\%) experienced 'good to average' level. There were 7 students $(36,8 \%)$ categorized in 'excellent to very good' level and 1 student $(5,3 \%)$ in 'very poor' level that faced difficulty in mechanics, such as lack of punctuation, capitalization, and spelling.

\section{DISCUSSION}

This research was done on a learning platform which was created by University of Sumatera Utara that serves connected general English started from A1 Beginner, A2 Elementary, B1 Pre-Intermediate, B2 Intermediate, B2+ Upper Intermediate, and C1 
Advanced. There is also a placement test on this platform for students to select or be enrolled into the right level of study from CEFR A1 to $\mathrm{C} 1$, including the questions paper, answers result, and scores. The first semester students' English proficiency on this platform starts from level B1 as a basic level for English Department students to understand writing

Figure I. Online Platform Display

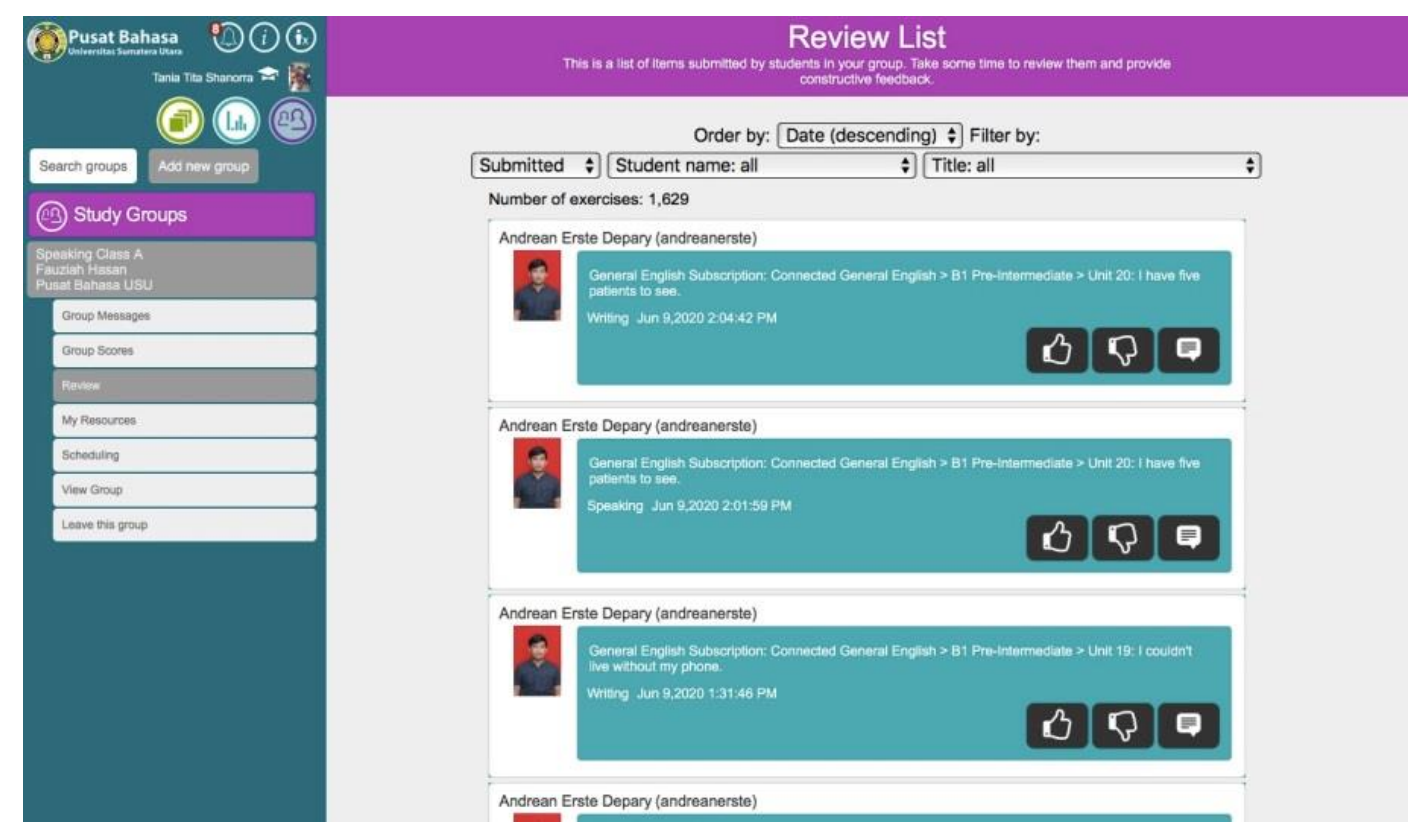

The students were asked to complete the assignments in units by filling the answer column on the platform. The focused unit to be analyzed was on the B1 PreIntermediate level with the title: "I couldn't live with my phone" and provided an instruction to predict about how technology may change lifetime. The instruction was automatically given before they started to write their text and they should follow the rules to write in a good form. On this online platform, it does not only explain about the rules and materials. The example is also given to the learners to make them easier to write their own tasks as the references. Their exercises were collected in online portfolios from units. After finishing their works, all of the assignments can be seen in review column. The teacher had given them the score on the scale of $10-90 \%$ as assessing their works. The assessing rubric score was done by the teacher by following the social learning instructions guide on platform. 
Figure II. Students' E-portfolios on Platform
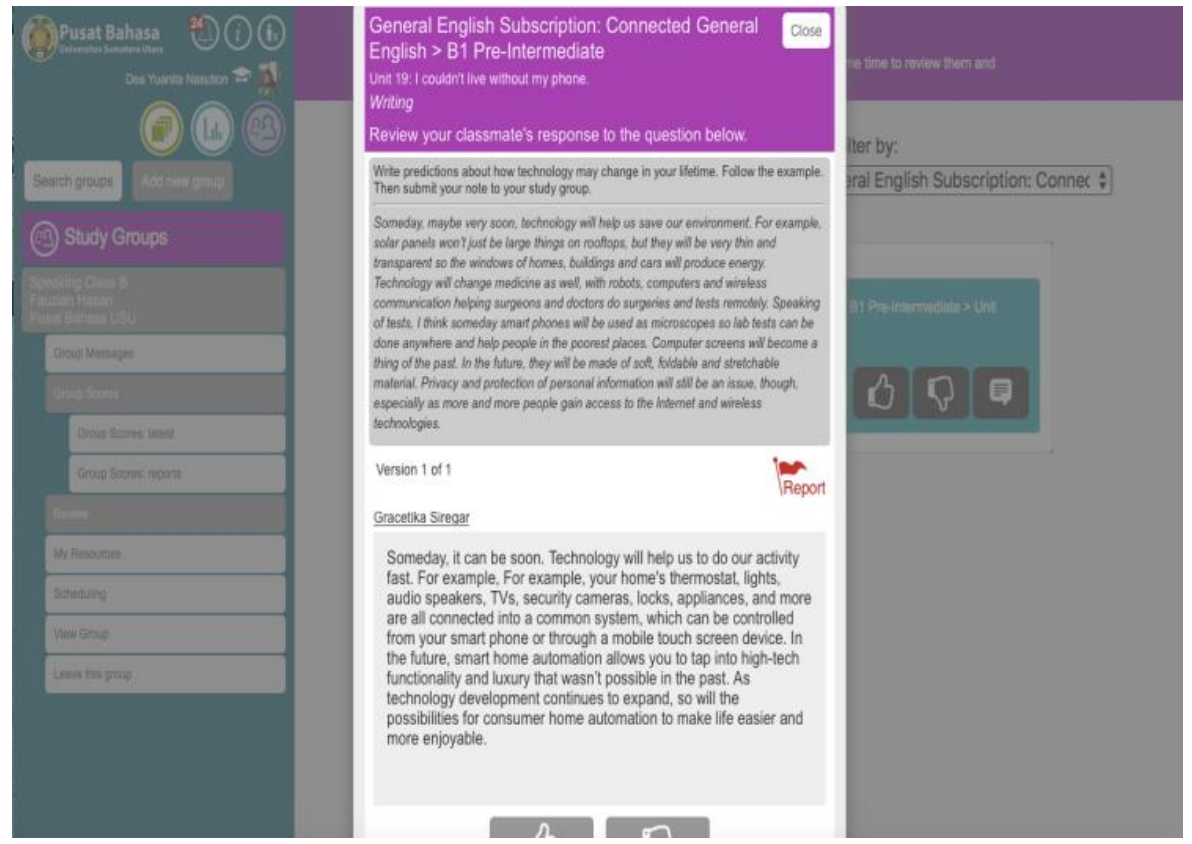

The peer review can also be done in this teaching and learning activity. The advantage that is gained in assessing like this is that students can interact and communicate with teachers and friends on the platform. However, only very few students did the peer review to correct their friends' writing. The teacher's assessment is also limited to ordinary arguments that are not too specific to explain in which categorize the students made mistakes in writing.

The assessment worked in this platform by entering to the study groups section and moved to review column to know the number of students who joined the class. From the online analysis, it can output the measurement results of students' writing ability. The students' paragraph is shown after clicking the name of the student. The analysis is carried out by correcting their writing on this platform and transferring it to an online checking form via computer software. The researcher used the computer-based assessment in Grammarly online platform checker to assess student's writing. 


\section{Figure III. Grammarly Checker Display}

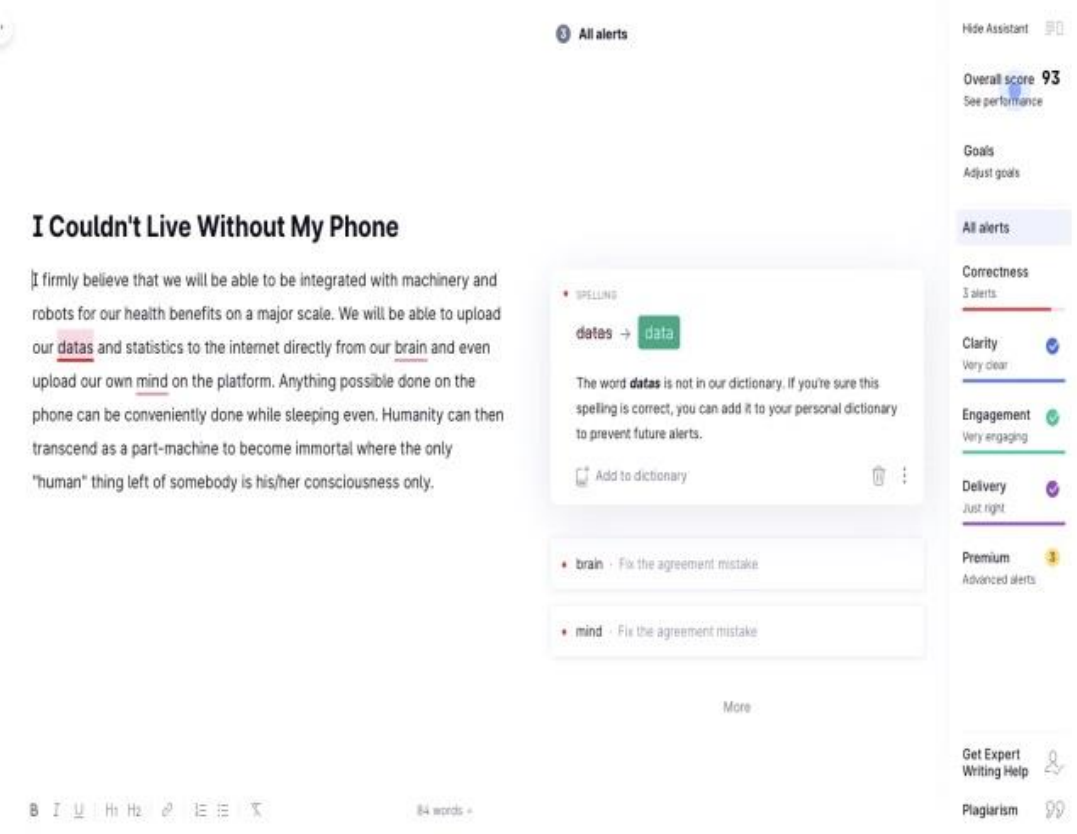

Grammarly provides such information by correcting the level of correctness, clarity, engagement, and delivery. It helped the researcher to find errors in students' writing, especially in language use and mechanics. By only typing the words of student's exercise, less than thirty seconds the result came out. The error is indicated by a colored underline that indicates errors or inaccuracies in writing.

This computer-based assessment (CBS) method has been applied by researcher started from: (1) Write the student's initial name; (2) Input of the word document; (3) Analysis of the document; (4) Scoring process. The participants' writing task has been collected afterwards, the computer software processes the quality of the sentences, including content, organization, mechanics, vocabulary and language use, calculates according to the scoring standards rubric, and then notifies the participants result score right on the platform.

Table IV. The Model of Assessment

\begin{tabular}{|c|c|c|c|}
\hline WRITE & INPUT OF THE & ANALYSIS THE & SCORING PROCESS \\
STUDENTS & WORD (2) & DOCUMENT (3) & \\
INITIAL NAME (1) & & & \\
& & & \\
\hline
\end{tabular}




\begin{tabular}{|l|l|l|l|}
\hline $\begin{array}{l}\text { Mark the first letter } \\
\text { of each word in the } \\
\text { name }\end{array}$ & Writing task & $\begin{array}{l}\text { Checking error } \\
\text { organization, content, } \\
\text { mechanics, vocabulary, } \\
\text { and language use }\end{array}$ \\
\hline
\end{tabular}

The assessment of the students' competency in writing was also done by three raters by using the model of the same table above. The students' works were scored by three seniors from English Department also who have a good skill in writing and high GPA in the department.

The writing content based on Jacobs et al (1981) scoring rubric, described some certain segments, included knowledgeable, substantive, through development of thesis, and relevant to assigned topic. Most participants belong to the highest level in content aspect who have a performance above a score of 27 included in 'excellent to very good' level. Students performed well in knowing much information and intelligence about the theme. In addition, they showed a good ability in understanding the core material of the lesson. Ideas from their understanding of the context could also be developed more broadly through their insight into the predictions of technological progress. By showing the quality of writing related to the learning topic, students performed such a good skill in content and could develop ideas that do not fall outside the main discussion. The second position of students were at the level of 'good to average'. This category can be described by these segments, included some knowledge of subject, adequate range, limited development of thesis, and mostly relevant to topic but lacks detail. The text shows some adequate range of the topic discussion and the student wrote content too far by starting with a story in a film that seemed ineffective. However, there were still participants despite having a high TOEFL score, they were unable to develop writing ideas in an efficient form. In this case, the participants provided limited knowledge of subject, little substance, and inadequate development of topic were categorized at the level of "fair to poor". The students performed a very short explanations related to technology without containing much knowledge. It also provided inadequate development of topic inasmuch as only contained few sentences that did not describe a detail explanation about the topic according to their opinion.

According to Jacob et al (1981) stated in how paragraph has a good organization, there are some specific items that refer to organization aspect included fluent expression, ideas 
clearly stated/supported, succinct, well- organized, logical sequencing, and cohesive. More than a half populations experienced organization in the level of 'excellent to very good'. In their sentences, it was clear that their ideas or expressions were shown in pouring their thought patterns into directional writing. The way to convey the idea was quite clear and efficient. Furthermore, students could deliver the sentences by giving some supporting strengthen opinion. Their texts were also short, concise, and easy to understand. They organized the paragraph well by writing the sequence of the sentences continuous and chronological order. In addition, the ideas in their stories could be developed by starting from the main idea first and then following it up with other supporting ideas. The students' arrangement in sentences was very attached to each other so as to form a unified unity. The students performed in 'good to average' level, the idea that they put forward was clear, but there were still sentences that were not attached and completed without the support of other ideas.

Jacob et al (1981) said the vocabulary aspect in writing ability can be shown in some fragments, there are sophisticated range, effective word/idiom choice and usage, word form mastery, and appropriate register. The research finding shows there was no one who experienced below average in vocabulary aspect. All of them revealed scores in range 16-20 or in the level of 'excellent to very good' and 'good to average'. The researcher found some of the juiciest verbiage ever devised as the sophisticated word. The choice of expressing idiom or word looked right and adequate. In addition, the students were be able to write the words comprehension appropriately. The students also be able to choose vocabulary according to the situation and style they used in writing. The participants who experienced the level of 'good to average' only had a minor mistake in paragraph related on the selection of diction or word that could be more effective or appropriate.

The language use aspect is one of the scoring method to assess students' work in writing skill. Language use contains the complicated constructions, agreement, tense, number, word order/function, articles, pronouns, and prepositions (Jacob et al, 1981). There were many students experienced the low capability in language use. The researcher found there were many participants experienced mistakes in agreement, tense, articles, and prepositions. There was only a single student who was able to master this component according to the research finding based on e-portfolio correctly. The average level of student was in 'good to average' by the dominant participants. The rest of it experienced in the level of 'fair to poor'. The researcher found there were many participants experienced mistakes in agreement, tense, articles, and prepositions. 
Mechanics aspect is the last components of writing skill based on Jacobs et al (1981) theory and he determines the mechanics in good writing involved demonstrate mastery of conventions, such as few errors of spelling, punctuation, capitalization, and paragraphing. The researcher found less than a quarter of the number of students could reach the level of 'excellent to very good'. The performance of mechanics aspect had a result that mostly students experienced the lack of spelling, punctuation, capitalization, and paragraphing error. The spelling often occur when the majority of participants spaced two words which should be combined into one single word. Punctuation errors often occur when students were unable to correctly place punctuation, such as: period (.); comma (,); and question mark (?). Then, the use of capital letters often found major errors in writing the pronoun " $I$ " in small letter, and they also wrote names that did not start with capital letters. Paragraphing error seemed often be found where the participants did convention by adding space before punctuation.

\section{CONCLUSION}

Measuring student competence in writing through an online platform is very helpful for teachers and students to interact with each other. According to the process of the language learning system through online application helps teachers work easier and faster in correcting students' scores. The result of the present study showed that most of the TOEFL top score in English Department batch 2019, Faculty of Cultural Sciences, Universitas Sumatera Utara students experienced high level of writing components. The present study also reveals that the most dominant level writing was 'excellent to very good'. The second most dominant level of writing was 'good to average' and 'fair to poor' was the third most. The last was the 'very poor' discovery on the significant components of students' writing skill. The students are proficient in vocabulary, but almost less proficient in the component language use and mechanics. The author would like to provide some recommendations in increasing the speed of using online media platforms in the language learning process, the instructions on the platform should provide clearer and more complete explanations in directing students use online learning strategies, teachers must be more involved in correcting student scores as a whole, and teachers should control student activities in emphasizing the motivation of providing peer feedback. 


\section{REFERENCE}

Ankawi, A. 2015. The Academic Writing Challenges Faced by Saudi Students Studying in New Zealand. International Journal of English Language Education, 8, 117-136.

Bram, B. 1995. Write Well Improving Writing Skill. Yogyakarta: Kanisius.

Brown, H. D. 2004. Language Assessment: Principles and Classroom Practices. New York: Pearson Education.

Catabay, M. Q. 2016. Error Analysis on Student's Writing. International Journal of Advanced Research in Management and Social Sciences, 5, 131-148.

Eisenhardt, K. M. 1989. Agency Theory: An Assessment and Review. Academy of Management Review, 14, 57-74.

Genlott, A. A. \& Grounlund, A. 2013. Improving Literacy Skills through Learning Reading by Writing: The iWTR Method Presented and Tested. Elsevier Ltd, 67, 98-104.

Hancock, B., Ockleford, E., \& Windridge, K. 2007. An Introduction to Qualitative Research. England: The NIHR Research Design Service for Yorkshire \& the Humber.

Jacobs, H. L., Wormuth, D. R., Zinkgraf, S. A., \& Hearfiel, V. F. 1981. Testing ESL Composition: A Practical Approach. Massachuset: Newbury House.

Morris, R., \& Smith, H. (1999). Orion Business Toolkit: Business Writing. United Kingdom: Orion Publishing Group.

National Academy of Engineering and National Research Council. 2006. Tech Tally: Approaches to Assessing Technological Literacy. 2006. Washington DC: The National Academy Press.

Nusrat, Adiba. 2016. Developing ESL Learners' Writing Skills: A Need Analysis. Journal of Teaching and Education, 5, 251-264.

Pamela, J. S. 1991. Test of English as a Foreign Language (6th Ed). New York: Barron's Educational Series Inc.

Polkinghorne, D. 1983. Methodology for The Human Sciences. Albany, NY: Human Sciences Press.

Pratiwi, K. D. 2016. Students' Difficulties in Writing English: A Study at The third Semester Students of English Education Program at University of Bengkulu Academic Year 2011-2012). Journal Of Linguistics and Language Teaching, 3, 106-119.

Redecker, Christine. 2013. The Use of ICT for The Assessment of Key Competences. Luxembourg: Publications Office of the European Union.

Richards, J. C. 2020. Assessing Writing Skills [Blog post]. Retrievied from https://www.professorjackrichards.com/assessing-writing-skills/ 
Ripley, M. 2009. Transformational Computer-Based Testing. In F. Scheuermann \& J. Björnsson (Eds.), The transition to computer-based assessment. Luxembourg: Office for Official Publications of the European Communities.

Sabarun. 2019. Needs Analysis on Developing EFL Paragraph Writing Materials at Kalimantan L2 Learners. Canadian Center of Science and Education, 12, 186-193.

Siozos, P., Palaigeorgiou, G., Triantafyllakos, G. \& Despotakis, T. 2009. Computer Based Testing Using "Digital Ink": Participatory Design of a Tablet PC Based Assessment Application for Secondary Education. Computers \& Education, 52, 811-819.

Weigle, S. C. 2002. Assessing Writing. United Kingdom: Cambridge University Press.

White, F. D. 1986. The Writer's Art: A Practical Rhetoric and Handbook. New York: Wadsworth Publishing Company. 2015.Why is Writing Hard. Oxford: Oxford University Press. 